\title{
Matrine induces cell cycle arrest and apoptosis in hepatocellular carcinoma cells via miR-122 mediated CG1/livin/survivin signal axis
}

\author{
Zhongjian $\mathrm{Pu}^{1}$, Yajun Wang ${ }^{2}$, Fei Ge ${ }^{3}$, Shilin Zhu ${ }^{4}$ Yuan Cheng ${ }^{1}$, Hua Liư ${ }^{4}$, Qijun \\ Dai $^{5}$, Haiqing Hua ${ }^{1 *}$ \\ ${ }^{1}$ Department of Oncology, Bayi Hospital Affiliated to Nanjing University of Chinese Medicine, Nanjing 210002, ${ }^{2}$ Department of \\ Oncology, Haian Hospital of Traditional Chinese Medicine, Haian 226600, ${ }^{3}$ Department of Gastroenterology, Haian Hospital of \\ Traditional Chinese Medicine, Haian 226600, ${ }^{4}$ Department of Oncology, Bayi Hospital Affiliated to Nanjing University of \\ Chinese Medicine, Nanjing 210002, ${ }^{5}$ Department of Orthopedics, Haian Hospital of Traditional Chinese Medicine, Haian \\ 226600, ${ }^{6}$ Department of Neurology, Haian Hospital of Traditional Chinese Medicine, Haian 226600, PR China
}

*For correspondence: Email: mqsvz9@163.com

\begin{abstract}
Purpose: To study the impact of matrine on cell cycle and apoptotic changes in hepatoma cells, and the mechanism involved.

Methods: Human hepatoma cell line HepG2 was treated with different concentrations of matrine. The blank control cells were maintained in 1640 medium only. The influence of matrine on proliferative ability was determined with 3-(4,5)-dimethylthiahiazo (-z-y1)-3,5-di- phenytetrazoliumromide (MTT) method. Flow cytometry was used to determine its effect on cell cycle and apoptosis; RT-PCR (reverse transcription-polymerase chain reaction) was applied to assay the mRNA expressions of miR-122, cyclin G1 (CG1), livin and survivin mRNA, while the protein expressions of CG1, livin and surviving were assayed by Western blotting.

Results: Matrine time- and dose-dependently suppressed the proliferative capacity of the cells. At a concentration of $0.5 \mathrm{mg} / \mathrm{mL}$, matrine had no significant effect on the cell cycle. However, $1.0 \mathrm{mg} / \mathrm{mL}$ matrine blocked the cell cycle in $\mathrm{G} 1$ phase, while $1.5 \mathrm{mg} / \mathrm{mL}$ matrine blocked HepG2 cells in G2/M phase $(p<0.05)$. Moreover, matrine induced apoptosis in HepG2 cells, and markedly downregulated the expressions of miR-122 concentration- time-reliantly $(p<0.05)$. In addition, matrine markedly and concentration-dependently reduced mRNA and protein expression levels of CG1, livin and survivin, with the strongest inhibitory effect at a level of $1.5 \mathrm{mg} / \mathrm{mL}$.

Conclusion: Matrine induces cell cycle block and apoptotic changes in hepatoma cells through a mechanism related to regulation of the CG1/livin/survivin signal axis mediated by miR-122. Matrine may be a potential treatment for liver cancer. However, clinical trials are needed to confirm this potential.
\end{abstract}

Keywords: Matrine, miR-122, CG1/livin/survivin signal axis, Hepatoma cells, Stagnation, Apoptosis

This is an Open Access article that uses a fund-ing model which does not charge readers or their institutions for access and distributed under the terms of the Creative Commons Attribution License (http://creativecommons.org/licenses/by/4.0) and the Budapest Open Access Initiative (http://www.budapestopenaccessinitiative.org/read), which permit unrestricted use, distribution, and reproduction in any medium, provided the original work is properly credited.

Tropical Journal of Pharmaceutical Research is indexed by Science Citation Index (SciSearch), Scopus, International Pharmaceutical Abstract, Chemical Abstracts, Embase, Index Copernicus, EBSCO, African Index Medicus, JournalSeek, Journal Citation Reports/Science Edition, Directory of Open Access Journals (DOAJ), African Journal Online, Bioline International, Open-J-Gate and Pharmacy Abstracts 


\section{INTRODUCTION}

Liver cancer is a frequently diagnosed primary carcinoma, accounting for about $90 \%$ of all cases. China accounts for more than half of the 1 million new cases of HCC worldwide, and in recent years, cases of HCC have been increasing markedly. In addition, liver cancer is not easily diagnosed at the early stages, and it progresses rapidly. Thus, at the point of diagnosis, most patients are already in the middle and late stages of the disease, thereby limiting the clinical effectiveness of treatment, shortening the survival time and increasing mortality rate [1]. The pathogenesis of liver cancer is associated with multiple factors and multiple gene interactions. Some of the factors associated with incidence of HCC are hepatitis B virus infection, aflatoxin, alcohol and nitrosamines [2].

At present, the clinical treatment of hepatocellular carcinoma focuses mainly on surgery in combination with radiotherapy and chemotherapy. However, due to the adverse side effects of radiotherapy and chemotherapy, drug resistance and other problems may arise. Traditional Chinese medicine has unique advantages in enhancing the survival of patients with advanced hepatocellular carcinoma. Matrine is a bioactive substance extracted from dried roots of Sophora flavescens. It has antiviral, antiinflammatory, sedative, antihypertensive and immunomodulatory properties [3]. Investigations have shown that matrine effectively inhibited the proliferative and metastasis potential of tumors, and induced apoptosis and differentiation [4]. MicroRNA (miRNA) plays an important role in tumorigenesis. It inhibits the translation of target gene by binding to its 3'-terminal non-coding region. It has been reported that miR-122 is one of the unique miRNAs which regulate the proliferation liver cells and lipid metabolism $[5,6]$

The aim of study was to investigate the effect of matrine on hepatoma cells, as well as the underlying mechanism.

\section{EXPERIMENTAL}

\section{Reagents and instruments}

Human hepatocellular carcinoma cell line HepG2 was obtained from Shanghai Yiyan Biotechnology Co. Ltd. The reagents and instruments used, and their suppliers (in brackets) were: matrine (Aimeijie Technology Co. Ltd), calf serum (ChuzhouShinoda Biotechnology Co. Ltd), PCR Amplification Kit (Beijing See Microgene Technology Co. Ltd), miRNA Reverse
Transcription Kit (GeneCopoeia, USA); protein pre-staining marker (Beijing Beyosentai Biotechnology Co. Ltd), Trizol extract and RIPA protein lysate (Shanghai Yanjing Biotechnology Co. Ltd), and primary antibodies against cyclin G1 (CG1), livin and survivin (American Cell Signaling Company).

The instruments used and their sources were: ultra-pure water meter (Beijing Zeping Science and Technology Co. Ltd), micro-high-speed lowtemperature centrifuge (Sichuan Shuke Instrument Co. Ltd), pressure steam disinfector (Nanjing Beden Medical Co. Ltd), porous plate enzyme marker (Meigu Molecular Instrument (Shanghai) Co. Ltd), constant-temperature water bath (Shanghai Fuze Commercial Co. Ltd), flow cytometer (Shanghai Ranzhe Instrument Equipment Co. Ltd), electrophoresis instrument (Beijing Yiaobai Co. Ltd.), gel imaging system (Shanghai Jinpeng Analytical Instrument Co. Ltd.), and UV spectrophotometer (Beijing Anmage Trade Co. Ltd.).

\section{Cell culture and grouping}

Frozen HepG2 cells were taken out and thawed in a $37{ }^{\circ} \mathrm{C}$ water bath. They were maintained in IMDM spiked with FBS $(10 \%)$ at $37^{\circ} \mathrm{C}$ and $5 \%$ $\mathrm{CO}_{2}$. The cells were permitted to attain $80-90 \%$ confluence prior to digestion and passaging. Three groups of cells at logarithmic phase were set up. They were exposed to matrine at doses of $0.5,1.0,1.5 \mathrm{mg} / \mathrm{mL}$. Cells in the blank control received 1640 medium only.

\section{Determination of influence of matrine on proliferative potential}

This was determined with MTT assay. Logarithmic growth-phase cells were seeded in 96-well plates after removal of culture medium and rinsing with PBS. They received either matrine at doses of $0.5,1.0,1.5 \mathrm{mg} / \mathrm{mL}$, or 1640 medium only, followed by culturing at $37^{\circ} \mathrm{C}$ and 5 $\% \mathrm{CO}_{2}$ for $48 \mathrm{~h}$. After $44 \mathrm{~h}$ of culture, $10 \mu \mathrm{l}$ of MTT $(5 \mathrm{mg} / \mathrm{mL})$ was put into every well, followed additional $4 \mathrm{~h}$ of culture. Thereafter, the supernatant was replaced with $150 \mu \mathrm{LMSO}$ to dissolve the formazan crystals formed. The absorbance of the solution in each well was read at $490 \mathrm{~nm}$. Inhibition of cell proliferation $(\mathrm{H})$ was calculated as shown in Eq 1.

$H(\%)=\{(1-\mathrm{Ae}) / \mathrm{Ae}\} 100$

where $A e$ is absorbance of experimental group and $A c$ is absorbance of control group.

Trop J Pharm Res, February 2021; 20(2): 264 
Determination of influence of matrine on HepG2 cell cycle

This was determined using flow cytometry. Cells at logarithmic phase were inoculated in 6-well plates $\left(5 \times 10^{4}\right.$ cells/well), and were treated separately with matrine at doses of $0.5,1.0$ and $1.5 \mathrm{mg} / \mathrm{mL}$. A blank control group was set up. After $48 \mathrm{~h}$ of continuous culture, the cells were subjected to digestion and counted. Then, the cells $\left(1 \times 10^{6}\right.$ cells) were re-suspended in cooled absolute ethanol and centrifuged for $12 \mathrm{~h}$, and re-suspended once more. again. This was followed by addition of $50 \mu \mathrm{l}$ RNase solution and $400 \mathrm{~mL}$ of propidium bromide staining solution. After a 10-min incubation in darkness, the cells were analyzed using a flow cytometer.

\section{Determination of effect of matrine on mRNA expressions}

The mRNA expressions levels of miR-122, CG1, livin and survivin in HepG2 cells were determined using RT-PCR. TRIzol was used to extract total RNA from HepG2 cells in logarithmic growth phase. The content and integrity of the RNA extract were determined. Diluted RNA samples were subjected to reverse-transcription. The enzyme RNase was inactivated at $37{ }^{\circ} \mathrm{C}$ for $1 \mathrm{~h}$ and at $85{ }^{\circ} \mathrm{C}$ for $5 \mathrm{~min}$. The resultant cDNA was subjected to PCR, with GAPDH as internal reference gene, under the conditions: predenaturation at $95^{\circ} \mathrm{C}$ for $10 \mathrm{~min}, 95^{\circ} \mathrm{C}$ for $10 \mathrm{sec}$, $57{ }^{\circ} \mathrm{C}$ for $20 \mathrm{sec}$, and $72{ }^{\circ} \mathrm{C}$ for $10 \mathrm{sec}$. The $\mathrm{Ct}$ values of each target gene were obtained, and the relative gene expressions were calculated using the 2- $\triangle \triangle \mathrm{CT}$ method.

\section{Determination of effect of matrine on protein expressions}

Extraction of total from cells in various groups was done with RIPA buffer, and protein concentration was measured with BCA method. Following SDS-PAGE, the proteins were transferred to PVDF membrane, and the membrane was incubated with PBS solution without fat milk powder for $1 \mathrm{~h}$, shaken slowly for $2 \mathrm{~h}$, and washed thrice with PBST. Thereafter, the membrane was incubated overnight at $4{ }^{\circ} \mathrm{C}$ with primary antibodies against CG1, livin and survivin, each diluted 1:100. Thereafter, the membrane was rinsed thrice with TBST and incubated with HRP-linked $2^{\circ}$ antibody for $1 \mathrm{~h}$ at laboratory temperature, followed by rinsing with PBST. The protein bands were developed using electro-chemiluminescence.

\section{Statistical analysis}

All measurement data are presented as mean \pm standard deviation. Independent sample $t$-test was used for two-group comparison, while comparison amongst many groups was performed with ANOVA. Values of $p<0.05$ were taken as indicative of statistical significance. All statistical analyses were carried out with SPSS20.0 software package.

\section{RESULTS}

\section{Matrine suppressed cell proliferative capacity}

Matrine suppressed proliferative capacity of HepG2 cells. These results are shown in Table 1

Table 1: Influence of matrine on HepG2 cell proliferation

\begin{tabular}{lccc}
\hline $\begin{array}{l}\text { Matrine } \\
\text { concentr } \\
\text { ation } \\
\text { (mg/mL) }\end{array}$ & $\mathbf{2 4 h}$ & $\mathbf{4 8 h}$ & $\mathbf{7 2 h}$ \\
\hline 0.025 & $5.58 \pm 3.72$ & $10.11 \pm 7.74$ & $9.31 \pm 8.26$ \\
0.05 & $8.84 \pm 3.62$ & $12.11 \pm 7.52$ & $12.46 \pm 10.13$ \\
0.1 & $10.47 \pm 5.26$ & $16.25 \pm 7.85$ & $16.13 \pm 12.88$ \\
0.5 & $18.85 \pm 11.42$ & $29.58 \pm 6.62$ & $37.45 \pm 12.41$ \\
1.0 & $24.42 \pm 8.74$ & $34.85 \pm 3.62$ & $45.21 \pm 11.22$ \\
1.5 & $35.78 \pm 16.52$ & $57.62 \pm 14.03$ & $67.05 \pm 15.47$ \\
\hline
\end{tabular}

Values are mean \pm SD

\section{Influence on cell cycle}

Based on the results of MTT assay, matrine was used at concentrations of $0.5,1.0$ and $1.5 \mathrm{mg} / \mathrm{mL}$ in the determination of its effect on cell cycle. At a concentration of $0.5 \mathrm{mg} / \mathrm{mL}$, matrine produced no significant influence on the cell cycle (Table 2). However, $1.0 \mathrm{mg} / \mathrm{mL}$ dose blocked the cells in G1 stage, while at the higher dose of $1.5 \mathrm{mg} / \mathrm{mL}$, it blocked the cycle in G2/M stage.

Table 2: Influence of matrine on cell cycle

\begin{tabular}{lccc}
\hline Group & G1 stage & $\begin{array}{c}\text { G2/M } \\
\text { stage }\end{array}$ & S stage \\
\hline Control & $64.12 \pm 6.23$ & $11.52 \pm 2.13$ & $24.26 \pm 4.45$ \\
Matrine & $62.85 \pm 7.54$ & $11.44 \pm 2.60$ & $25.61 \pm 9.32$ \\
$(0.5 \mathrm{mg} / \mathrm{mL})$ & & & \\
$\begin{array}{l}\text { Matrine } \\
(1.0 \mathrm{mg} / \mathrm{mL})\end{array}$ & $75.23 \pm 6.48^{*}$ & $7.21 \pm 1.87$ & $17.56 \pm 5.52$ \\
$\begin{array}{l}\text { Matrine } \\
(1.5 \mathrm{mg} / \mathrm{mL})\end{array}$ & $51.12 \pm 7.03$ & $29.11 \pm 9.05^{*}$ & $19.78 \pm 3.15$ \\
\hline
\end{tabular}

Values are mean \pm SD. ${ }^{*} P<0.05$, vs the control

\section{Influence of matrine on apoptosis of HepG2 cells}

As shown in Table 3, matrine time- and dosedependently induced apoptosis in HepG2 cells ( $p$ 
$<0.05)$

Table 3: Apoptotic effect of matrine

\begin{tabular}{lccc}
\hline Group & $\mathbf{2 4 h}$ & $\mathbf{4 8 h}$ & $\mathbf{7 2 h}$ \\
\hline Control & $5.82 \pm 0.62$ & $7.78 \pm 1.52$ & $7.77 \pm 1.84$ \\
Matrine & $6.74 \pm 0.86$ & $12.12 \pm 1.26$ & $18.84 \pm 2.32$ \\
$(0.5 \mathrm{mg} / \mathrm{mL})$ & & & \\
$\begin{array}{l}\text { Matrine } \\
(1.0 \mathrm{mg} / \mathrm{mL})\end{array}$ & $10.62 \pm 0.48$ & $28.26 \pm 6.13$ & $36.42 \pm 2.33$ \\
$\begin{array}{l}\text { Matrine } \\
(1.5 \mathrm{mg} / \mathrm{mL})\end{array}$ & $17.47 \pm 6.23$ & $54.82 \pm 13.52$ & $67.68 \pm 8.45$ \\
\multicolumn{4}{l}{ Values are presented as mean \pm SD } \\
\end{tabular}

\section{Effect of matrine on miR-122 in HepG2 cells}

Relative to control group, matrine markedly downregulated the expression of miR-122 in HepG2 cells, while the expression of miR-122 was markedly upregulated $(p<0.05)$. These results are presented in Figure 1.



Figure 1:: Effect of matrine on the expression of miR122 in HepG2 cells. ${ }^{*} P<0.05$, vs control

Effect of matrine on CG1/livin/survivin signaling pathway in HepG2 Cells

As shown in Table 4 and Figure 2, matrine dosedependently downregulated the mRNA and protein expressions of CG1, livin and survivin, relative to control.

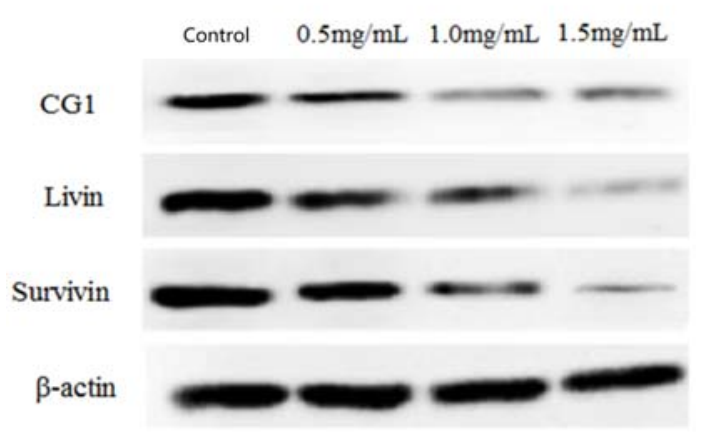

Figure 2: Effect of matrine on protein expressions of CG1, livin and surviving

\section{DISCUSSION}

Extracts from Chinese Traditional Medicine (TCM) have been widely used in clinical practice to induce apoptosis in tumor cells. The involvement of inhibition of telomerase activity in the anti-cancer effects of drugs has continued to attract the attention of researchers. Studies have shown that TCMs induce apoptosis by arresting the cell cycle at some phases, and studies have demonstrated that telomerase plays an important role in cell immortalization and malignancy $[7,8]$. Matrine, an effective anticancer compound isolated from Sophora flavescens, is a tetracyclic quinazine molecule with numerous pharmacological properties. Studies have demonstrated that matrine suppresses tumor proliferation, and induces apoptosis and tumor cell adhesion [9]. In addition, matrine reverses drug resistance of tumors, mitigates the toxic and adverse side effects of chemotherapeutic agents, and enhances the survival of cancer patients.

Some investigators have reported that oxymatrine blocked the G0/G1 stage of hepatoma cell lines, decreased fraction of cells in $S$ phase, and inhibited cell proliferation [10]. Moreover, matrine inhibited the proliferation of hepatoma cell line SMMC-7721 in a dosedependent manner. At moderate concentrations, oxymatrine inhibited tumor cell growth, but it had

Table 4: Effect of matrine on the mRNA and protein expressions of CG1, livin and survivin in HepG2 cells

\begin{tabular}{lcccccc}
\hline \multirow{2}{*}{ Group } & \multicolumn{2}{c}{ CG1 } & \multicolumn{2}{c}{ Livin } & \multicolumn{2}{c}{ Survivin } \\
\cline { 2 - 7 } & mRNA & Protein & mRNA & Protein & mRNA & protein \\
\hline Control & $0.46 \pm 0.05$ & $0.54 \pm 0.02$ & $0.48 \pm 0.02$ & $0.70 \pm 0.03$ & $0.44 \pm 0.03$ & $0.67 \pm 0.04$ \\
Matrine & $0.37 \pm 0.04^{*}$ & $0.47 \pm 0.03^{*}$ & $0.41 \pm 0.01^{*}$ & $0.63 \pm 0.04^{*}$ & $0.35 \pm 0.04^{*}$ & $0.59 \pm 0.04^{*}$ \\
$(0.5 \mathrm{mg} / \mathrm{mL})$ & $0.25 \pm 0.03^{*}$ & $0.33 \pm 0.21^{*}$ & $0.28 \pm 0.04^{*}$ & $0.55 \pm 0.05^{*}$ & $0.30 \pm 0.02^{*}$ & $0.42 \pm 0.03^{*}$ \\
$\begin{array}{l}\text { Matrine } \\
(1.0 \mathrm{mg} / \mathrm{mL})\end{array}$ & & & & & \\
Matrine & $0.19 \pm 0.02^{* \#}$ & $0.20 \pm 0.02^{* \#}$ & $0.21 \pm 0.05^{* \#}$ & $0.36 \pm 0.09^{* \#}$ & $0.18 \pm 0.04^{* \#}$ & $0.30 \pm 0.04^{* \#}$ \\
\hline$(1.5 \mathrm{mg} / \mathrm{mL})$ & 0
\end{tabular}

Values are mean \pm SD. ${ }^{*} P<0.05$, vs control; ${ }^{\#} p<0.05$, vs matrine groups 
very minimal effect on cell growth at low concentrations [11].

MicroRNAs (miRNAs) are a non-coding singlestranded RNAs with lengths of 19-25 nucleotides. They participate in the regulation of cell proliferation, differentiation and apoptosis. These miRNAs regulate the expressions of several target genes at the translation level through generation of one or more complementary base pairs of partial sequences of mRNA [12]. In tumorigenesis, different miRNAs may act on the same target gene to form a complex regulatory network. High or low expressions of miRNAs are akin to the effects of oncogenes or tumor suppressor genes, and are involved in the formation, survival and migration of tumors. Similar variations in the expressions of specific miRNAs are implicated in the pathogenesis and growth of hepatocellular carcinoma [13]. About $70 \%$ of the total liver miRNAs is MiR-122 which is one of the important regulators of liver differentiation [14]. Some researchers have found that $\mathrm{miR}-122$ regulates cell proliferation and DNA repair by downregulating CG1 [15]. Livin and survivin are anti-apoptosis proteins closely related to apoptosis regulatory genes.

The results of this investigation indicate that matrine blocked HepG2 cell proliferative capacity in a time- and dose-based fashion: $1.0 \mathrm{mg} / \mathrm{mL}$ blocked the cells in $\mathrm{G} 1$ stage, but $1.5 \mathrm{mg} / \mathrm{mL}$ blocked the cells in G2/M phase. Moreover, it was found that matrine triggered apoptotic changes in these cells. These results suggest that matrine suppresses cell proliferation and promotes apoptosis by prolonging cell cycle through inhibition of the growth of HepG2 cells. In addition, matrine upregulated miR-122 and downregulated the expressions of CG1, livin and survivin. Thus, matrine enhanced apoptosis of hepatoma cells through a mechanism involving the CG1/livin/survivin signaling pathway.

\section{CONCLUSION}

Matrine induces apoptotic changes and cell cycle block in HCC cells through a mechanism involving regulation of the miR-22-mediated CG1/livin/survivin signaling pathway. Matrine may be a potential treatment for liver cancer. However, clinical trials are needed to confirm this potential.

\section{DECLARATIONS}

\section{Acknowledgement}

The study was supported by Nantong Municipal
Science and Technology Project (No. JCZ18096).

\section{Conflict of interest}

No conflict of interest is associated with this work.

\section{Authors' contribution}

We declare that this work was done by the authors named in this article and all liabilities pertaining to claims relating to the content of this article will be borne by the authors. Haiqing Hua was involved in the conception and design of the study, manuscript revision, funding support and study supervision. Zhongjian $\mathrm{Pu}$ contributed to design of the study as well as the experiments, data analysis and manuscript writing. Others contributed to the design of the study and interpretation of the data. All authors read and approved the final manuscript.

\section{Open Access}

This is an Open Access article that uses a funding model which does not charge readers or their institutions for access and distributed under the terms of the Creative Commons Attribution License (http://creativecommons.org/licenses/by/ 4.0) and the Budapest Open Access Initiative (http://www.budapestopenaccessinitiative.org/rea d), which permit unrestricted use, distribution, and reproduction in any medium, provided the original work is properly credited.

\section{REFERENCES}

1. Tian F, Hongwei L, Guishuai L, Ting L, Changzheng $W$, Qin $H$, Lexing $Y$, Bo $S$, Linna $G$, Shanna $H$, et al. Tumorderived exosomal miR-1247-3p induces cancerassociated fibroblast activation to foster lung metastasis of liver cancer. Nat Commun 2018; 9(1): 191-198.

2. Silvia A, Le-Xing $Y$, Robert FS. The Role of CancerAssociated Fibroblasts and Fibrosis in Liver Cancer. Annual Review of Pathology Mechanisms of Disease 2017; 12(1): 153-186.

3. Zhang MF, Shen YQ. Research progress on pharmacological action and clinical application of matrine against liver cancer. Chin Sci Technol Data Catalogue- Chinese Herbs 2020; 043 (001): 157-165.

4. Yang Jb, Li HJ. Effects of matrine and Oxymatrine on proliferation and apoptosis of hepatoma cells. Chin J Clin Pharmacol 2018; 263(09): 61-63.

5. Xu G, Wang Y, Wu LG. miR-122 upregulating the radiosensitivity of liver cancer cells HepG2 through apoptosis pathway. Chin J Cancer Prev Treatment 2017; 24(16): 1130-1136.

Trop J Pharm Res, February 2021; 20(2): 267 
6. Sun $Y$, Jin JG, Mi WY, Hao W. Zhang SR, Meng $Q$, Zhang ST. Long Non-coding RNA UCA1 Targets miR122 to Promote Proliferation, Migration, and Invasion of Glioma Cells. Oncol Res 2017; 26(1): 103-110.

7. Wen YJ, Zhou J. Study on the effect of matrine injection on the changes of serum Egfl7, AFP and OPN in patients with hepatocellular carcinoma after surgery. Chin Tradit Med Sci Technol 2017; 24 (1): 12-15.

8. Kang SC, Yang W, Zheng Y. Matrine inhibits ERK signaling pathway, a target of HepG2 hepatoma cells. Liver 2019; 24 (2): 187-189.

9. Zhi $X$, Chen $X$, Su JC. Research progress on pharmacological effects of matrine. J Chengdu Univ Tradit Chin Med 2017; 40(1): 123-127.

10. Chen J, Zhou W, Song B. Effect of Matrine Injection on Egfl7, AFP, OPN in Patients with Primary Liver Cancer after Radical Resection. J Modern Integr Tradit Chin West Med 2018; 27 (30): 3389-3392.

11. He $X X, Y u W$, Yao S. Effect and mechanism of Matrineinduced autophagy in hepatoma HepG2 cells. J Nanchang Univ 2018; 58 (2): 1-4.
12. Kentaro J, Yuri K, Yuko U, Kaori K, Hiroaki H, Wataru N, Kazutoshi $F$, Motohide U, Norio N, Kazutake T. High miR-122 expression promotes malignant phenotypes in cCRCC by targeting occludin. Int J Onco 2017; 51(1): 289-297.

13. Caviglia GP, Abate ML, Gaia S, Petrini E, Bosco C, Olivero A, Rosso C, Ciancio A, Pellicano R, Saracco $G M$, et al. Risk of hepatocellular carcinoma in HBV cirrhotic patients assessed by the combination of miR122, AFP and PIVKA-II. Panminerva Medica 2017; 59(4): 283-289.

14. Juan MB, Ryan R, Maria JG, Samson TJ, Tasneem M, Kalpana $G$. The role of miR-122 in the dysregulation of glucose-6-phosphate dehydrogenase (G6PD) expression in hepatocellular cancer. Sci Rep 2018; 8(1): 9105-9110.

15. Nahid D, Abbas SL, Masoud S, Hori G. The Combination of miR-122 Overexpression and Let-7f silencing Induce Hepatic Differentiation of Adipose Tissue-Derived Stem Cells. Cell Biol Int 2017; 41(10): 1083-1092. 